\title{
Improving the patient experience in real-time
}

\author{
Author: Katherine Islip
}

\begin{abstract}
Aims
In the current, busy climate, we focus on delivering quick and safe care. However, is this sometimes at the expense of recognising patients as individual people with lives outside the hospital walls, and taking the time to ensure they are kept fully informed. My vision is to give patients more opportunities to tell us what is important to them while in hospital, and improve their understanding of what their hospital stay will entail. I aim to improve patient satisfaction scores by $10 \%$, relating to how well they feel they've been listened to, how well informed they have felt and how well they have felt their individual needs have been addressed, on one of the acute admissions wards at St James's University Hospital.
\end{abstract}

\section{Methods}

I have performed four 'plan, do, study, act' cycles using a variety of means to ask patients what is important to them. For the most recent cycle I am using cards which say 'Tell us something about yourself which will help us to care for you', with a section saying 'I am not completely clear about' followed by 'my diagnosis', 'my tests', 'my treatment' and 'how long I am expected to be in hospital', with tick boxes next to each. I have been giving these cards to patients, encouraging clinical staff to endeavour to address what is written on them, and asking both patients who have and patients who have not received cards, satisfaction questions related to those described above.

\section{Results}

Based on small numbers so far, mean scores relating to how well patients have felt listened to and how well patients have felt their individual needs have been addressed have been higher in the group who have received cards. However, the mean scores relating to how well-informed patients have felt have been higher in the group who have not received cards (Table 1). All patients have felt that the cards are a good idea.

\section{Conclusion}

The idea of giving patients more opportunities to express their individual needs has been well-received and appeared to result in a

Author: Royal College of Physicians chief registrar, Leeds Teaching Hospitals NHS Trust, UK

\begin{tabular}{|c|c|c|}
\hline $\begin{array}{l}\text { On a scale of } 1-5 \\
1=\text { poor; } 5 \text { = excellent }\end{array}$ & $\begin{array}{l}\text { Patients not } \\
\text { given cards } \\
\text { (mean score) }\end{array}$ & $\begin{array}{l}\text { Patients } \\
\text { given cards } \\
\text { (mean score) }\end{array}$ \\
\hline $\begin{array}{l}\text { How well have you felt you've } \\
\text { been listened to? }\end{array}$ & 3.6 & 4.3 \\
\hline $\begin{array}{l}\text { How well informed have you } \\
\text { felt about your hospital stay? }\end{array}$ & 4.1 & 3.9 \\
\hline $\begin{array}{l}\text { How well have you felt your } \\
\text { individual needs have been } \\
\text { addressed? }\end{array}$ & 3.4 & 4.8 \\
\hline
\end{tabular}

small improvement in certain patient satisfaction scores. A change in wording, more concerted effort to encourage patients to use the cards, and ensuring staff respond to what patients are writing is required to improve these scores further and address how well patients feel informed. The next step will also involve trialling the use of the cards in other clinical areas.

\section{Conflict of interest statement}

None. 